THIS IS A PRE-PRINT. THE PAPER IS CURRENTLY UNDERGOING PEER-REVIEW AND IS SUBJECT TO CHANGE.

"Not racist, but..."

Beliefs about immigration restrictions, collective narcissism and justification of ethnic extremism

Aleksandra Cichocka ${ }^{1,2}$, Konrad Bocian $^{1,3}$, Mikolaj Winiewski ${ }^{4}$, and Flavio Azevedo ${ }^{5}$

${ }^{1}$ School of Psychology, University of Kent

${ }^{2}$ Institute of Psychology, Nicolaus Copernicus University

${ }^{3}$ Department of Psychology in Sopot, SWPS University of Social Sciences and Humanities

${ }^{4}$ Faculty of Psychology, University of Warsaw

${ }^{5}$ Friedrich-Schiller University of Jena, Germany

Author Note

Aleksandra Cichocka (iD https://orcid.org/0000-0003-1703-1586

Konrad Bocian (iD https://orcid.org/0000-0002-8652-0167

Mikolaj Winiewski (D) https://orcid.org/0000-0003-1703-1586

Flavio Azevedo (D) https://orcid.org/0000-0001-9000-8513

We have no known conflict of interest to disclose.

The preparation of this article was supported by Polish National Science Centre grants 2018/29/B/HS6/00658 awarded to Konrad Bocian and 2017/26/M/HS6/00114 awarded to Mikolaj Winiewski. The authors would like to thank Eric Kaufmann and Nikhil Sengupta for comments on an earlier draft of this manuscript and Katarzyna Stryczynska for her help in manuscript preparation.

Correspondence concerning this article should be addressed to Aleksandra Cichocka, School of Psychology, Keynes College, University of Kent, Canterbury CT2 7NZ, UK. Email: a.k.cichocka@kent.ac.uk. 


\begin{abstract}
Surveys show that a majority of people across countries believe that seeking lower immigration to help maintain the majority group's population share is racially self-interested, rather than racist. If this belief indeed reflects in-group concern, it should be linked to ingroup identification - a positive attachment to and solidarity with one's group. However, if it is a defensive strategy to protect the in-group's privileged position, this belief should be linked to collective narcissism. In four studies, we examined the associations between immigration restriction beliefs and dominant (national or White) identities. Relative to ingroup identification, national narcissism (Studies 1: UK, $N=220$, and 2: Poland, $N=1285$ ) and ethnic narcissism (Studies 3a: US, $N=1516$, and 3b: US, $N=2402$ ) were stronger predictors of a belief that it is not racist (vs. racist) to want immigration restrictions. This belief was also associated with justifying collective violence against migrants (Study 2) and supporting the alt-right (Studies 3a-3b).
\end{abstract}

Keywords: racism, collective narcissism, in-group identification, collective violence, alt-right 
"Not racist, but..."

\section{Beliefs about immigration restrictions, collective narcissism and justification of ethnic}

\section{extremism}

“A white American who identifies with her group and its history supports a proposal to reduce immigration. Her motivation is to maintain her group's share of America's population." Is this person "being racist" or "just acting in her racial self-interest, which is not racist"? Kaufmann (2017; p. 19) asked a similar question to thousands of people in WEIRD and non-WEIRD countries. It seems that, across all samples he studied, most respondents believe it is racially self-interested, rather than racist, for a White majority to react to social or demographic changes by seeking lower immigration to help maintain their share of the population (Kaufmann, 2018). Here, we investigate the psychological concomitants of this belief, focusing both on its relationship with commitment to the in-group and its potential implications for intergroup hostility and the acceptance of racist social movements.

Kaufmann (2018) argues that the main factors determining whether someone considers White's desire to curb immigration for cultural reasons as racist (vs. self-interested) are partisanship and political ideology — this conviction is stronger among liberals than among conservatives. For example, in one US survey (Kaufmann, 2017), as many as $73 \%$ of White Clinton voters and as few as $11 \%$ of White Trump voters agreed that it was racist for White Americans to seek to reduce immigration to maintain their group's share of the population. Similarly, in the UK, $47 \%$ of White British Remain voters, compared to $5 \%$ of White British Leave voters, said it would be racist for a White Briton to do so. These differences notwithstanding, a conviction that immigration restrictions are not racist, but simply an expression of racial self-interest, is shared by most respondents in the US, the UK, and the 18 other countries surveyed by Kaufmann (2018). The prevalence of this belief might be one reason why being concerned about demographic changes is sometimes seen as reasonable and 
justifiable (e.g., Goodhart, 2014). For example, Kaufmann argued: “[F]or the conservative members of the white majority who are attached to their group and its historic presence, I think that sense of loss and wanting to slow down that sense of loss is an understandable motivation" (Chotiner, 2019; para. 10). Here, rather than discussing what might and what might not be justifiable, we focus on the correlates of the belief that protecting the interests of a dominant majority is a mere expression of one's interests.

A critical point of this debate relies on the distinction between in-group and out-group attitudes (e.g., Allport, 1954; Turner et al., 1979; Levin \& Sidanius, 1999). Viewing immigration restrictions as racially self-interested allegedly stems from concern for the ingroup, which does not need to necessarily translate into out-group prejudice or hostility (Allport, 1954; Brewer, 1999; see also Jardina, 2019; Earle \& Hodson, 2020). And if it is simply motivated by in-group attachment, Kaufmann argues, then the need to slow down ethnocultural change should not be considered racist (Chotiner, 2019). Yet, there is scarce evidence for this position. In Whiteshift, Kaufmann (2018) reports results of one pilot study which suggests that those White Americans that are moderately or strongly identified with their ethnic group, do not consider the protection of White interests as racist. However, there are different ways of identifying with one's in-group which can produce divergent intergroup attitudes (e.g., Ashmore et al., 2004; Blank \& Schmidt, 2003; Cichocka, 2016; de Figueiredo \& Elkins, 2003; Roccas et al., 2008).

Researchers distinguish more secure, constructive ways of identifying with one's social groups (be it one's nation, ethnic group or a sports team), from ones that are more destructive and defensive (e.g., Adorno et al., 1950; Cichocka, 2016). For example, in the context of national identities, love for one's country captured by patriotism is often differentiated from the more confrontational nationalism, which assumes the need to dominate other nations (Kosterman \& Feschbach, 1989; see also Bizumic et al., 2020; Mummendey et 
al., 2001; Schatz et al., 1999). Beyond the specific context of national identity, some researchers differentiate in-group identification from collective narcissism (Cichocka, 2016; Golec de Zavala, Cichocka, \& Bilewicz, 2013).

In-group identification can be defined as a self-investment in the group, which encompasses being satisfied with group membership, feelings of solidarity with other group members as well as the importance of the group to the self (Leach et al., 2008; Tajfel, 1978). In-group identification implies a strong attachment and commitment to the group. It facilitates mutual cooperation, trust (Brewer, 1999; Putnam, 2000) and engagement on behalf of the group (e.g., Bilewicz \& Wojcik, 2010; Huddy \& Khatib, 2007; van Zomeren et al., 2008). In line with Brewer's (1999) theorizing about in-group and out-group attitudes being often independent of each other, in-group identification does not necessarily translate into prejudicial attitudes towards out-groups (e.g., Jackson et al., 2001; Pehrson, Brown, et al., 2009; Pehrson, Vignoles, et al., 2009). We argue that if beliefs about immigration restrictions being racial self-interest are indeed an expression of a mere concern for the in-group, they should be linked to stronger in-group identification - that is the emotional significance one attaches to the in-group and its members (Leach et al., 2008; Tajfel, 1978).

However, another possibility is that construing culturally motivated immigration restrictions as not racist is a defensive strategy to protect the in-group's privileged position. Research from the US context suggests that reminders of demographics shifts can drive concerns that Whites would lose their cultural dominance and be discriminated against in the future (Craig \& Richeson, 2017; Craig et al., 2018). If preoccupation with protecting the ingroup image and position takes priority, then beliefs about immigration restriction not being racist should be linked to a defensive (rather than secure) in-group identity. Being defensive about one's in-group can be understood as collective narcissism (Golec de Zavala et al., 2009). 
Collective narcissism is an excessive belief in in-group greatness, accompanied by the idea that the in-group deserves special treatment and recognition from members of other groups (Golec de Zavala et al., 2009). Collective narcissism is associated a conviction that others aim to threaten or undermine the in-group and conspire against it (e.g., Cichocka et al., 2016; Golec de Zavala \& Cichocka, 2012; Guerra et al., 2020). Those scoring high in collective narcissism tend to respond with hostility to any sings of criticism or lack of appreciation of the in-group (Golec de Zavala, Cichocka, \& Iskra-Golec, 2013; Gries et al., 2015), and are prejudiced towards groups they find threatening (e.g., Dyduch-Hazar et al., 2019; Golec de Zavala, Cichocka, \& Bilewicz, 2013; Hadarics et al., 2020; Marchlewska et al., 2019).

Collective narcissism is also associated with biased processing of information in a way that favours the in-group (Bocian et al., 2020; Cislak et al., 2020). In a series of experiments, participants scoring high in collective narcissism judged actions favouring the interests of ingroup members as more moral than similar actions favouring the interests of an out-group. For example, evaluations of the US Senate's decision to confirm Brett Kavanaugh to the supreme court depended on partisanship, but this effect was strengthened by partisan collective narcissism. There is also evidence that collective narcissism is associated with downplaying in-group members' moral transgressions (e.g., Klar \& Bilewicz, 2017). Overall, these findings suggest that collective narcissism might be linked to perceptions of threat from immigrants and the need to justify restrictions of immigration. A belief that restrictionism is just racial self-interest (and not racism) might then be linked to collective narcissism, rather than to in-group identification. This would suggest this belief is motivated by maintaining the in-group's positive image and position, rather than caring for in-group members.

Such a link might have further implications for intergroup attitudes. Collective narcissism is a robust predictor of intergroup violence and hostility (Golec de Zavala, 
Cichocka, \& Iskra-Golec, 2013; Jasko et al., 2020). When measured in the context of White identity, it is also related to support for White supremacist movements, for example, the Unite the Right rally that took place in Charlottesville in 2017 (Alexander-Grose, 2018). We then propose to investigate whether viewing immigration restrictions as racist (vs. not) would also be associated with intergroup hostility or support for extreme political movements. As Kaufmann (2017) writes: "Do restrictionists fear, hate or look down upon those of other ethnic backgrounds? If the answer is yes, they are racist by any definition of the term." We will put this possibility to the test.

\section{Overview of the present studies}

In four surveys conducted in the UK, Poland, and the US, two of which were nationally representative, we examined the in-group and out-group attitudes associated with beliefs about immigration restrictions. First, we investigated whether a conviction that it is not racist (vs. racist) to want to maximise the demographic advantage of one's group is associated with secure or narcissistic identity. Second, we investigated whether such conviction would be linked with an overt justification of collective violence and support for the alt-right $-\mathrm{a}$ loosely organized far-right movement linked to White supremacy beliefs (e.g., Forscher \& Kteily, 2019; Lyons, 2017). We tested these predictions focusing on the dominant national identities (Study 1 and 2) and ethnic identities (Study 3a and 3b). In all regression models, we accounted for any effects of political ideology. We checked our analyses controlling for age and gender. Unless noted otherwise, the results remain the same when we include these demographic variables as covariates.

\section{Study 1}

In Study 1, we sought to examine whether beliefs about racial self-interest are indeed associated with the strength of in-group identity. We compared the effects of in-group identification versus the more defensive collective narcissism. The study was conducted in the 
UK. Because our focus is on racial self-interest, we tested our models among participants who identified as White British.

\section{Method}

Participants and procedure. Study 1 involved a sample of the 467 first year psychology students, $86 \%$ women, Mean age $=19.26, S D=2.31$, recruited in 2018-2019 at a UK university as part of a subject pool. Because our focus was on the dominant majority identity, we conducted our analyses with a sub-sample of 220 students who identified as "British" and "White British".

\section{Measures.}

Collective narcissism was measured with a 5-item version of the Collective Narcissism Scale (Golec de Zavala, Cichocka, \& Bilewicz, 2013), e.g., "If my country had a major say in the world, the world would be a much better place.", "Not many people seem to fully understand the importance of people of my nationality." Participants responded on a scale from $1=$ strongly disagree to $7=$ strongly agree $(\alpha=.81, M=2.73, S D=1.05)$.

In-group identification was measured with five items capturing social identification (e.g., Cameron, 2004), e.g., "Being my nationality gives me a good feeling”, "I feel solidarity with people of my nationality." Participants responded on a scale from 1 = strongly disagree to $7=$ strongly agree $(\alpha=.90, M=4.58, S D=1.12)$.

Political ideology was measured with a single item. Participants were asked to report their political orientation on a 5 -point scale from $1=$ extremely left-wing to $5=$ extremely right-wing $(M=2.66, S D=0.84)$.

Racial self-interest was measured with a single item from Kaufmann (2017): “A White Briton who identifies with her group, and its history supports a proposal to reduce immigration. Is this person...?" Participants indicated one of three answers: (1) Racist, (2) Racially self-interested, which is not racist, or 3) I do not know. In our sample, 53 (24\%) 
participants indicated that the person was racist, and 96 (44\%) that the person was racially self-interested. The third option was chosen by 71 (32\%) participants, and following Kaufmann (2017), these participants were excluded from the analyses.

\section{Results and discussion}

We first examined zero-order correlations between key variables (Table 1). We then tested in-group identification, collective narcissism and political ideology as predictors of viewing immigration restrictions as self-interested (i.e., not racist; coded as 1) rather than as racist (coded as 0) with a binominal logistic regression, Nagelkerke's $R^{2}=0.21, \mathrm{C} \& \mathrm{~S} R^{2}=$ $.15,-2$ log-likelihood $=168.66$. In this model, the odds of perceiving immigration restrictions as not racist (vs. racist) were significantly higher for those scoring higher on collective narcissism, $O R=1.59[1.02,2.47], B=0.46, S E=0.23, p=.041$, but they were not significantly related to the strength of in-group identification, $O R=1.28[0.90,1.83], B=$ $0.25, S E=0.18, p=.170$. This finding suggests that a belief that immigration restrictions are racially self-interested, is associated with a defensive, narcissistic national identity, rather than identification with the nation understood as the emotional attachment to the group.

Replicating Kaufman (2017), we found that those with more conservative views were more likely to indicate that immigration restrictions were racially self-interested rather than racist, $O R=1.65[1.06,2.58], B=0.50, S E=0.23, p=.027^{1}$.

\section{Table 1}

Table of Correlations for Main Variables (Study 1)

\begin{tabular}{llll}
\hline Variables & 1 & 2 & 3 \\
\hline
\end{tabular}

\footnotetext{
${ }^{1}$ Note that when we controlled for age and gender, both the effect of collective narcissism, $O R=1.53, p=.062$, and identification, $O R=1.40, p=.082$, became only marginally significant, and the effect of ideology became non-significant, $O R=1.46, p=.110$. This could be due to a relatively small sample we relied on in Study 1 . We therefore sought to replicate our models with much larger samples in subsequent studies.
} 


\section{Racial Self-Interest}

$(0=$ RAC, $1=$ SELF-INT)

2. Collective narcissism $.31 * * *$

3. In-group identification $.30 * * * \quad .52 * * *$

4. Political ideology $.29 * * * \quad .28 * * * \quad .32 * * *$

Note . RAC = Racist, SELF INT = Racially self-interested. $* * * p<.001$

\section{Study 2}

In Study 2, we sought to replicate the findings of Study 1 in a different context. We tested similar models in a larger, nationally representative survey collected in Poland - $\mathrm{a}$ country that is extremely ethnically homogenous, with a majority White population (Gudaszewski, 2015). We additionally wanted to examine the behavioural intentions associated with beliefs about immigration restrictions. If a conviction that such restrictions are not racist is mostly driven by one's care for their in-group, it should not translate into overt intergroup hostility. Therefore, we decided to examine the association between beliefs about immigration restrictions and collective violence — arguably, an extreme expression of ingroup animosity. To account for the possibility that any links between immigration restrictions beliefs and intergroup hostility could be simply attributed to collective narcissism or political ideology, we controlled for these two factors as well as in-group identification in the regression models for collective violence.

To measure the acceptance of different violent behaviours toward minority groups we used a method by Winiewski and Bulska (2020). This method presents participants with a scenario in which a majority is in conflict with an ethnic minority that is newly settled in a town. As such, this methodology is well suited to capture people's potential reactions to immigration. 


\section{Method}

Participants and procedure. Study 2 involved a 2018 nationally representative sample of 1285 Polish adults, 52\% women, aged $18-84$, Mean age $=43.80, S D=15.44^{2}$. Data were collected with the use of an online research panel (http://www.panelariadna.com). Participants were recruited using a quota sampling strategy (based on population distribution of age, gender, place of residence and education level). Because Poland is ethnically homogenous, the survey did not include questions about participants' ethnic identity. All participants were included in the analysis.

\section{Measures.}

Collective narcissism was measured with the 5-item version of the Collective Narcissism Scale (Golec de Zavala, Cichocka, \& Bilewicz, 2013), e.g., "The Polish nation deserves special treatment”. Participants responded on a scale from $1=$ strongly disagree to 6 = strongly agree $(\alpha=.92, M=3.63, S D=1.25)$.

In-group identification was measured with six items taken from the Social Identification Scale by Cameron (2004), e.g., "I feel strong ties to other Polish people”, "In general, I'm glad to be Polish". Participants responded on a scale from 1 = strongly disagree to $5=$ strongly agree $(\alpha=.92, M=3.69, S D=0.87)$.

Political ideology was measured with a single item. Participants were asked to report their political ideology on a scale from $1=$ definitely conservative to $7=$ definitely liberal, which we recoded so that higher scores indicate greater conservatism $(M=3.45, S D=1.78)$.

Racial self-interest was measured with the single item adapted from Kaufmann (2017): “A White Pole who identifies with her group and its history supports a proposal to reduce immigration. Is this person...?” Participants answered indicating one of three options: (1) Racist, (2) Racially self-interested, which is not racist, (3) I do not know/Hard to say. In

\footnotetext{
2 This sample was also used in another project (BLINDED), which tested different hypotheses.
} 
this sample, 298 (23\%) participants indicated that the person is racist, $578(45 \%)$ that the person is racially self-interested, and 409 (32\%) did not know or could not tell (as in Study 1, the latter group was excluded from the analysis).

Collective violence was measured using a scale capturing acceptance of collective violent actions (Winiewski \& Bulska, 2020). Participants were presented with a short description of an intergroup conflict between the majority (in-group) and a minority group of new residents in a town. Next, they were assigned one of four target minority groups at random: Jews, Vietnamese, Roma or Ukrainians. These groups were selected as four most distinctive or largest minority groups in Poland (see also Cichocka et al., 2015). Finally, participants were presented with several possible behaviours of in-group members towards the minority and rated the extent to which each of the actions was justified. We used a composite score of 12 items measuring direct confrontational behaviours, e.g., "Native inhabitants of the town beat up the newcomers" or "Employees of shops and restaurants refuse to serve the newcomers". Participants responded on a scale from $1=$ fully unjustified to $7=$ fully justified $(\alpha=.97, M=2.44, S D=1.40)$.

\section{Results and discussion}

We first examined zero-order correlations (Table 2). We then tested in-group identification, collective narcissism and political ideology as predictors of viewing immigration restrictions as self-interested (i.e., not racist; coded as 1) rather than racist (coded as 0) with a binominal logistic regression, Nagelkerke's $R^{2}=.32, \mathrm{C} \& \mathrm{~S} R^{2}=.23,-2 \log$ likelihood $=894.86$. In this model, the odds of perceiving immigration restrictions as not racist (vs. racist) were significantly higher for those scoring higher on collective narcissism, $O R=2.61[2.18,3.12], B=0.96, S E=0.09, p<.001$, but significantly lower for those with stronger in-group identification, $O R=0.66[0.53,0.83], B=-0.41, S E=0.12, p<.001$. Thus, in the Polish context, we found that those identified with the national group in a secure, non- 
narcissistic way, were more likely to view immigration restrictions as racist than as racially self-interested. Again, in line with Study 1 and past work by Kaufmann (2017), we found that immigration restrictions were more likely to be perceived as not racist (vs. racist) among those with more conservative views, $O R=1.27[1.16,1.40], B=0.24, S E=0.05, p<.001$.

\section{Table 2}

Table of Correlations for Main Variables (Study 2)

\begin{tabular}{|c|c|c|c|c|}
\hline Variables & 1 & 2 & 3 & 4 \\
\hline \multicolumn{5}{|l|}{ 1. Racial self-interest } \\
\hline \multicolumn{5}{|l|}{$(0=\mathrm{RAC}, 1=\mathrm{SELF}$ INT $)$} \\
\hline 2. Collective narcissism & $.44 * * *$ & - & & \\
\hline 3. In-group identification & $.17 * * *$ & $.62 * * *$ & - & \\
\hline 4. Political ideology & $.29 * * *$ & $.26 * * *$ & $.12 * * *$ & - \\
\hline 5. Collective violence & $.29 * * *$ & $.19 * * *$ & $-.06 *$ & $.10 * * *$ \\
\hline
\end{tabular}

Note. RAC = Racist, SELF INT = Racially self-interested.

$* p<.05, * * * p<.001$

We then sought to examine whether beliefs about immigration restrictions would be associated with intergroup hostility. We examined their associations with justification of collective violence. We also accounted for any overlapping effects of collective narcissism, in-group identification and political ideology. We found that perceiving immigration restrictions as not racist (vs. racist) was a significant predictor of justification of collective violence (Table 3$)^{3}$. This finding indicates that perceptions of racial self-interest are not only an expression of in-group attitudes, but are also linked to overt out-group hostility. This result was observed even when we accounted for any effects of collective narcissism which, in line

\footnotetext{
${ }^{3}$ Note that the pattern of results was very similar across the four target groups.
} 
with past research, was positively associated with justification of collective violence (e.g., Golec de Zavala et al., 2009; Golec de Zavala, Cichocka, \& Iskra-Golec, 2013; Golec de Zavala \& Cichocka, 2012; Jasko et al., 2020). National identification, in contrast, was negatively associated with justification of collective violence (see e.g., Cichocka, 2016; Golec de Zavala, Cichocka, \& Bilewicz, 2013). Political ideology was not significantly related to justification of collective violence.

\section{Table 3}

Results of a Regression Analysis Predicting Collective Violence Justification (Study 2)

\begin{tabular}{|c|c|c|c|c|}
\hline Predictor variable & $B(S E)$ & $B \mathrm{CI}_{95 \%}$ & $\beta$ & $p$ \\
\hline Constant & $2.09(0.20)$ & $1.69,2.49$ & & $<.001$ \\
\hline Political ideology & $0.02(0.03)$ & $-0.03,0.07$ & 0.03 & .401 \\
\hline Collective narcissism & $0.30(0.05)$ & $0.20,0.39$ & 0.27 & $<.001$ \\
\hline In-group identification & $-0.33(0.07)$ & $-0.46,-0.20$ & -0.21 & $<.001$ \\
\hline Racial Self-Interest $(0=$ RAC, $1=$ SELF INT) & $0.57(0.11)$ & $0.36,0.78$ & 0.19 & $<.001$ \\
\hline$F$ & \multicolumn{4}{|c|}{31.22} \\
\hline$R^{2}$ & \multicolumn{4}{|c|}{.13} \\
\hline
\end{tabular}

Note. RAC $=$ Racist, SELF INT = Racially self-interested.

\section{Study 3a}

In Studies 1 and 2, we examined the role of national identities in predicting perceptions of immigration restrictions. In Studies 3a and 3b, we sought to test whether similar effects would be observed when ethnic (i.e., White) identity is considered. We also examined whether seeing immigration restrictions as not racist would be associated with support for political movements advocating for racial supremacy. To this end, we measured participants attitudes towards the alt-right (Forscher \& Kteily, 2019; Lyons, 2017). 
We report results based on two larger datasets: (1) an exploratory, quota-based sample that was nationally representative (Study 3a), and (2) a confirmatory (replication) convenience sample from the same population that we analysed to minimize the influence of false positives and to maximize the generalizability and robustness of our results (Study $3 b$ ). Both samples completed the same study materials in the same order and manner.

\section{Method}

We hired Cint (www.cint.com), a survey research firm that recruits participants from a pool of over 13 million U.S. citizens, to recruit a nationally representative sample of Americans in the months preceding the 2020 US Presidential Election (from July 01 to July 22, 2020). The quotas were designed to match that of the 2018 US Census' Current Population Survey (CPS) on age, income, education and gender, with a maximum percentual difference of $5 \%$ at the bracket level. The sample has achieved a high level of national representativeness. We took a number of steps to ensure that the quality of the data would be high. These included following professional recommendations to minimize problems of careless responding and satisficing behaviour in online survey studies (Meade \& Craig, 2012). Detailed description of the sample and exclusions is presented in the Supplement. The sample included 2000 participant, 51.5\% women, age distribution: 18-24 years (11.65\%), 25-34 (17.8\%), 35-44 (16.75\%), 45-54 (16.55\%), 55-65 (16.6\%), and older than 65 (20.65\%).

White participants constituted $75.8 \%$ of the sample and these participants were included in the final analysis $(N=1516)$.

\section{Measures.}

Collective narcissism was measured with a 9-item version of the Collective Narcissism Scale (Golec de Zavala et al., 2009). Participants responded to the items after reporting their ethnicity and their instruction read "When thinking in terms of the group with which you just identified, to what extent do you agree or disagree with the following 
statements", e.g., "It really makes me angry when others criticize Whites.", "If Whites had a major say in the world, the world would be a much better place." Participants responded on a scale from $1=$ strongly agree to $9=$ strongly disagree $(\alpha=.90 ; M=3.94, S D=1.67)$.

In-group identification was measured with one item "I identify with being White"" Participants responded on a scale from $0=$ strongly disagree to $100=$ strongly agree $(M=$ $80.89, S D=23.34)$.

Political ideology was measured with a single item, which read "Overall, where would you place yourself, on the following scale of liberalism-conservatism?". Participants responded on a scale from $0=$ strongly liberal to $100=$ strongly conservative $(M=54.67, S D$ $=30.40)$.

Racial self-interest was measured with the single item adapted from Kaufmann (2017): “A White American who identifies with her group and its history supports a proposal to reduce immigration. Is this person...? Participants answered indicating one of three answers: 1 = just acting in her racial self-interest, which is not racist; $2=$ being racist; $3=\mathrm{I}$ don't know." In this sample, $768(38 \%)$ participants indicated that the person is just acting in his/her racial self-interest; $580(29 \%)$ that the person is being racist, and $652(33 \%)$ did not know or could not tell (the latter were excluded from the analysis).

Support for the Alt-right was measured with one item: "How positive or negative do you feel concerning the following social movements?" whose target was "The Alt-Right Movement”. Participants responded on a scale from $0=$ extremely negative to $100=$ extremely positive $(M=36.51, S D=28.85)$.

\section{Results}

Zero-order correlations are presented in Table 4. We then tested a binominal logistic regression with in-group identification, collective narcissism and political ideology as predictors of viewing immigration restrictions as self-interested (coded as 1; as opposed to 
racist, coded as 0), Nagelkerke's $R^{2}=.49, \mathrm{C} \& S R^{2}=.36,-2$ log-likelihood $=889.08$. In this model, the odds of perceiving immigration restrictions as not racist (vs. racist) were significantly higher for those scoring higher on collective narcissism, $O R=1.70[1.51,1.90]$, $B=0.53, S E=0.06, p<.001$, and for those with more conservative views, $O R=1.03[1.03$, 1.04], $B=0.03, S E=0.00, p<.001$. The odds of perceiving immigration restrictions as not racist (vs. racist) were also significantly higher for those with higher ethnic in-group identification, $O R=1.01[1.00,1.02], B=0.01, S E=0.00, p<.001$.

\section{Table 4}

Table of Correlations for Main Variables (Study 3a)

\begin{tabular}{lcccc}
\hline Variables & 1 & 2 & 3 & 4 \\
\hline 1. Racial Self-Interest & & & & \\
$(0=$ RAC, $1=$ SELF INT $)$ & & & & \\
2. Collective narcissism & $.52 * * *$ & - & & - \\
3. In-group identification & $.32 * * *$ & $.34 * * *$ &. & \\
4. Political ideology & $.54 * * *$ & $.43 * * *$ & $.28 * * *$ & - \\
5. Alt-right support & $.37 * * *$ & $.31 * * *$ & $.24 * * *$ & $.32 * * *$ \\
\hline
\end{tabular}

Note. RAC $=$ Racist, SELF INT = Racially self-interested. $* * * p<.001$

We then sought to examine whether beliefs about immigration restrictions would be associated with more positive attitudes towards the alt-right, accounting for any effects of collective narcissism, in-group identification or political ideology. We found that perceiving immigration restrictions as not racist (vs. racist) was indeed a significant predictor of support for the alt-right movement (see Table 5). We also found that both White collective narcissism and White identification, as well as political conservatism, were predictors of positive attitudes towards the alt-right. 
BELIEFS ABOUT IMMIGRATION RESTRICTIONS

\section{Table 5}

Results of a Regression Analysis Predicting Attitudes towards the Alt-Right (Study 3a)

\begin{tabular}{|c|c|c|c|c|}
\hline Predictor variable & $B(S E)$ & B $\mathrm{CI}_{95 \%}$ & $\beta$ & $p$ \\
\hline Constant & $0.16(3.07)$ & $-5.86,6.19$ & & .957 \\
\hline Political ideology & $0.16(0.03)$ & $0.09,0.22$ & 0.17 & $<.001$ \\
\hline Collective narcissism & $3.61(0.58)$ & $2.46,4.76$ & 0.22 & $<.001$ \\
\hline In-group identification & $0.09(0.04)$ & $0.01,0.17$ & 0.07 & .022 \\
\hline Racial self-interest & & & & \\
\hline$(0=\mathrm{RAC}, 1=\mathrm{SELF}$ INT) & $8.64(2.19)$ & $4.34,12.94$ & 0.14 & $<.001$ \\
\hline$F$ & & \multicolumn{3}{|c|}{69.86} \\
\hline$R^{2}$ & & \multicolumn{3}{|c|}{.22} \\
\hline
\end{tabular}

Note. RAC = Racist, SELF INT = Racially self-interested.

\section{Study 3b}

\section{Method}

We administered the same survey as in Study 3a to a large convenience sample of American adults in the months preceding the 2020 US Presidential Election (from July 1 to July 24, 2020). The study was again conducted through Cint, and we applied the same quality-control criteria as in Study 3a. The final sample included 2938 participants, $69.54 \%$ women, with the age distribution of 18-24 years (8.75\%), 25-34 (12.8\%), 35-44 (16.3\%), 45-54 (15.62\%), 55-65 (18.52\%), and older than 65 (28.01\%). The final analyses were conducted for White $(81.76 \%)$ participants only $(N=2402)$. Measures were identical as the ones used in Study 3a. Means and standard deviations are reported in Table 6. Collective narcissism formed a reliable scale $(\alpha=.90)$.

\section{Results}


Zero-order correlations are presented in Table 6. We tested in-group identification, collective narcissism and political ideology as predictors of viewing immigration restrictions as self-interested (coded as 1 ; as opposed to racist, coded as 0 ) with a binominal logistic regression, Nagelkerke's $R^{2}=.49, \mathrm{C} \& \mathrm{~S} R^{2}=.36,-2$ log-likelihood $=1419.6$. In this model, the odds of perceiving immigration restrictions as not racist (vs. racist) were significantly higher for those scoring higher on collective narcissism, $O R=1.85[1.69,2.03], B=0.62, S E$ $=0.05, p<.001$, and for those with more conservative views, $O R=1.03[1.02,1.03], B=$ 0.03, $S E=0.00, p<.001$. Again, the odds of perceiving immigration restrictions as not racist (vs. racist) were also significantly higher for those with higher ethnic identification, $O R=$ $1.01[1.01,1.02], B=0.02, S E=0.00, p<.001$.

Table 6

Table of Correlations for Main Variables (Study 3b)

\begin{tabular}{|c|c|c|c|c|c|c|}
\hline Variables & $M$ & $S D$ & 1 & 2 & 3 & 4 \\
\hline $\begin{array}{l}\text { 1. Racial self-interest } \\
(0=\text { RAC, } 1=\text { SELF INT) }\end{array}$ & - & - & - & & & \\
\hline 2. Collective narcissism & 3.83 & 1.65 & $.54 * * *$ & - & & \\
\hline 3. In-group identification & 83.01 & 21.62 & $.28 * * *$ & $.27 * * *$ & - & \\
\hline 4. Political ideology & 54.21 & 30.64 & $.52 * * *$ & $.41 * * *$ & $.21 * * *$ & - \\
\hline 5. Alt-right support & 35.98 & 28.67 & $.36 * * *$ & $30 * * *$ & $.22 * * *$ & $.31 * * *$ \\
\hline
\end{tabular}

Note. RAC $=$ Racist, SELF INT $=$ Racially self-interested.

$* * * p<.001$

We then sought to examine whether beliefs about immigration restrictions would be associated with support for the alt-right, accounting for any effects of collective narcissism, in-group identification and political ideology. As in Study 3a, we found that perceiving immigration restrictions as not racist (vs. racist) was a significant predictor of support for the 
alt-right (Table 7). We again also found that White collective narcissism, White identification and conservatism were associated with more positive attitudes towards the alt-right.

\section{Table 7}

Results of a Regression Analysis Predicting Attitudes towards the Alt-right (Study 3b)

\begin{tabular}{|c|c|c|c|c|}
\hline Predictor variable & $B(S E)$ & B CI $95 \%$ & $\beta$ & $p$ \\
\hline Constant & $-0.04(2.70)$ & $-5.35,5.26$ & & .988 \\
\hline Political ideology & $0.14(0.03)$ & $0.09,0.19$ & 0.15 & $<.001$ \\
\hline Collective narcissism & $2.54(0.48)$ & $1.60,3.48$ & 0.15 & $<.001$ \\
\hline In-group identification & $0.14(0.03)$ & $0.08,0.20$ & 0.11 & $<.001$ \\
\hline Racial self-interest & & & & \\
\hline$(0=$ RAC, $1=$ SELF INT) & $10.09(1.73)$ & $6.69,13.49$ & 0.17 & $<.001$ \\
\hline$F$ & & \multicolumn{3}{|c|}{90.67} \\
\hline$R^{2}$ & & \multicolumn{3}{|c|}{.19} \\
\hline
\end{tabular}

Note. RAC = Racist, SELF INT = Racially self-interested.

\section{General Discussion}

In four surveys, conducted in different national contexts, we investigated the psychological concomitants of beliefs about immigration restrictions. We based our research on Kaufmann's (2017) question on whether seeking immigration restrictions for cultural reasons is racist or simply an expression of racial self-interest, which should not be considered racist. As Kaufmann (2017; 2018), we found that most respondents in our samples thought that such a belief was not racist. However, the prevalence of this opinion does not preclude it from being associated with potentially problematic in-group or out-group attitudes.

Our studies indicate that viewing immigration restrictions as racially self-interested (vs. racist) is robustly associated with national (Studies 1-2) and White (Studies 3a-3b) 
collective narcissism. We found less consistent evidence that it would be linked to in-group identification. National identification was either unrelated (Study 1) or negatively (Study 2) related to seeing immigration restrictions as self-interested (vs. racist). We found positive effects of White identification in Studies $3 a$ and $3 b$, but these effects were weaker than those observed for White collective narcissism. Furthermore, they were observed for a single-item identification measure that does not directly capture feelings of solidarity and commitment we measured in Studies 1 and 2. Overall, our results suggest that viewing the protection of one's group's share of the population as mere racial self-interest might be an expression of a defensive need to protect the image of the group, rather than of attachment to the in-group and its members.

We further examined the potential implications of one's beliefs about immigration restrictions. Rather unsurprisingly, past work suggests that those who believe restricting immigration for ethnocultural reasons is not racist, were also more willing to support such restrictions (Kaufmann, 2018). However, we found they would also be willing to support overt forms of intergroup hostility. In Study 2, believing immigration restrictions were not racist (vs. racist) increased the likelihood of justifying collective violence against newly settled minority groups. In Studies 3a and 3b, this belief was associated with more positive views of the alt-right — a movement linked to White supremacy beliefs, dominance and blatant hostility towards minorities (Forscher \& Kteily, 2019). These relationships were observed over and above any effects of political ideology, collective narcissism or in-group identification.

Our analyses also demonstrated that independent of immigration beliefs, collective narcissism was predictive of greater justification of collective violence, while in-group identification without the narcissistic component was negatively associated with this outcome. This is in line with past research showing that while collective narcissism is robustly related 
to intergroup animosity, in-group identification without the narcissistic component can be linked to greater tolerance of out-groups (Cichocka et al., 2018; Golec de Zavala, Cichocka, \& Bilewicz, 2013). Indeed, a positive attachment to the in-group does not necessarily imply out-group hostility, but such attachment does not seem to be responsible for viewing immigration restrictions as self-interested.

In Studies 3a and 3b, we additionally found that Whites' collective narcissism was a strong predictor of positive attitudes towards the alt-right. This is consistent with past research linking Whites' collective narcissism to support for the Unite the Right rally (AlexanderGrose, 2018). This finding complements research on the psychological profile of the alt-right (Forscher \& Kteily, 2019), indicating that it might not only be linked to needs for in-group dominance but also to ideas of one's ethno-national group's underappreciated greatness (see also Gest et al., 2017; Gronfeldt et al., in press).

In this research, we investigated individual factors associated with one's beliefs about slowing down immigration for cultural reasons. Future research would do well to examine how exposure to the idea that such beliefs should be considered racist (vs. not) affects the public's attitudes and behaviours. For example, in July 2019 President Donald Trump Tweeted that the "the Squad" - a group of Democrat Congresswomen, should go back to their countries (Yglesias, 2019). Yet, he claimed these tweets were not racist, and that he did "not have a Racist bone" in his body (Fabian, 2019). He has also repeatedly failed to condemn racist movements and organisations (e.g., Cineas, 2020; Kendi, 2020). Future studies could examine the knock-on effects of failing to call out more or less overtly prejudicial behaviours as racist. Given our reliance on correlational data, such studies might also be well suited to establish causal effects of beliefs about immigration restrictions on intergroup attitudes and policy support. 
One limitation of the current research is that we examined implications of beliefs about immigration restrictions among members of dominant ethno-national groups, who made judgments about their in-group member's immigration attitudes. The goal of Kaufmann's (2018) project was to directly compare how people would view similar attitudes expressed by ethnic minorities versus majorities. For example, he found that White Clinton voters were less likely to view immigration restriction preferences as racist when they were expressed by a minority, compared to a White person. The effect was reversed for White Trump voters (although this difference was smaller than that observed for Clinton voters). Future research would do well to examine whether immigration restrictions beliefs have similar in-group and out-group correlates depending on the target ${ }^{4}$, as well as when measured among minority respondents.

The overall aim of this research was to examine implications of different views on restricting immigration for cultural reasons or to maintain one's ethnic groups share of the population. Our goal was not to establish whether such views are in fact racist, justifiable, or reasonable. Instead, we sought to understand what sort of in-group and out-group attitudes would be associated with beliefs about racial self-interest. Even if most people believe some acts are not racist, it does not necessarily mean they would not be linked to racist outcomes.

\footnotetext{
${ }^{4}$ A preliminary study (reported in the Supplement) examined whether target change would affect the association between collective narcissism and perceptions of immigration restrictions. We found that collective narcissism predicted greater likelihood of viewing such restrictions as not racist (vs. racist), regardless of whether the described target was a member of the in-group or out-group.
} 


\section{References}

Adorno, T. W., Frenkel-Brunswik, E., Levinson, D. J., \& Sanford, R. N. (1950). The authoritarian personality. Harpers.

Alexander-Grose, N. (2018). Investigating the relationship between collective narcissism and ethnic extremism. Unpublished dissertation.

Allport, G. W. (1954). The nature of prejudice. Addison-Wesley.

Ashmore, R. D., Deaux, K., \& McLaughlin-Volpe, T. (2004). An organizing framework for collective identity: Articulation and significance of multidimensionality. Psychological Bulletin, 130(1), 80-114. https://doi.org/10.1037/0033-2909.130.1.80

Bilewicz, M., \& Wojcik, A. (2010). Does identification predict community involvement? Exploring consequences of social identification among the Jewish minority in Poland. Journal of Community \& Applied Social Psychology, 20(1), 72-79. https://doi.org/10.1002/casp.1012

Bizumic, B., Monaghan, C., \& Priest, D. (2020). The return of ethnocentrism. Political Psychology. https://doi.org/10.1111/pops.12710

Blank, T., \& Schmidt, P. (2003). National identity in a united Germany: Nationalism or patriotism? An empirical test with representative data. Political Psychology, 24(2), 289-312. https://doi.org/10.1111/0162-895X.00329

Bocian, K., Cichocka, A., \& Wojciszke, B. (2020). Moral tribalism: Moral judgments of actions supporting ingroup interests depend on collective narcissism. Journal of Experimental Social Psychology, 93. https://doi.org/10.1016/j.jesp.2020.104098

Brewer, M. B. (1999). The psychology of prejudice: Ingroup love and outgroup hate? Journal of social issues, 55(3), 429-444. https://doi.org/10.1111/0022-4537.00126

Cameron, J. E. (2004). A three-factor model of social identity. Self and Identity, 3(3), 239262. https://doi.org/10.1080/13576500444000047 
Chotiner, I. (2019, April 30). A political scientist defends White identity politics. The New Yorker. https://www.newyorker.com/news/q-and-a/a-political-scientist-defends-whiteidentity-politics-eric-kaufmann-whiteshift-book

Cichocka, A. (2016). Understanding defensive and secure in-group positivity: The role of collective narcissism. European Review of Social Psychology, 27(1), 283-317. https://doi.org/10.1080/10463283.2016.1252530

Cichocka, A., Golec de Zavala, A., Marchlewska, M., Bilewicz, M., Jaworska, M., \& Olechowski, M. (2018). Personal control decreases narcissistic but increases nonnarcissistic in-group positivity. Journal of Personality, 86(3), 465-480. https://doi.org/10.1111/jopy.12328

Cichocka, A., Marchlewska, M., Golec de Zavala, A., \& Olechowski, M. (2016). "They will not control us": Ingroup positivity and belief in intergroup conspiracies. British Journal of Psychology, 107(3), 556-576. https://doi.org/10.1111/bjop.12158

Cichocka, A., Winiewski, M., Bilewicz, M., Bukowski, M., \& Jost, J. T. (2015). Complementary stereotyping of ethnic minorities predicts system justification in Poland. Group Processes \& Intergroup Relations, 18(6), 788-800. https://doi.org/10.1177/1368430214566891

Cineas, F. (2020, September 29). Trump was asked to denounce White supremacy. He wouldn't. Vox. https://www.vox.com/2020/9/29/21494841/trump-proud-boys-standwhite-supremacy

Cislak, A., Pyrczak, M., Mikiewicz, A., \& Cichocka, A. (2020). Brexit and Polexit: Collective narcissism is associated with the support for leaving the European Union. Social Psychological Bulletin, 15(1), Article e2645. https://doi.org/10.32872/spb.2645 
Craig, M. A., \& Richeson, J. A. (2017). Information about the US racial demographic shift triggers concerns about anti-White discrimination among the prospective White “minority”. PloS One, 12(9), e0185389. https://doi.org/10.1371/journal.pone.0185389

Craig, M. A., Rucker, J. M., \& Richeson, J. A. (2018). Racial and political dynamics of an approaching "majority-minority” United States. The Annals of the American Academy of Political and Social Science, 677(1), 204-214. https://doi.org/10.1177/0002716218766269

de Figueiredo, R. J. P., \& Elkins, Z. (2003). Are patriots bigots? An inquiry into the vices of in-group pride. American Journal of Political Science, 47(1), 171-188. https://doi.org/10.1111/1540-5907.00012

Dyduch-Hazar, K., Mrozinski, B., \& Golec de Zavala, A. (2019). Collective narcissism and in-group satisfaction predict opposite attitudes toward refugees via attribution of hostility. Frontiers in Psychology, 10, Article 1901. https://doi.org/10.3389/fpsyg.2019.01901

Earle, M., \& Hodson, G. (2020). Questioning white losses and anti-white discrimination in the United States. Nature Human Behaviour, 4(2), 160-168. https://doi.org/10.1038/s41562-019-0777-1

Fabian, J. (2019, July 16). Trump: I don't have a racist bone in my body. The Hill. https://thehill.com/homenews/administration/453253-trump-i-dont-have-a-racist-bonein-my-body

Forscher, P. S., \& Kteily, N. S. (2019). A psychological profile of the Alt-Right. Perspectives on Psychological Science, 15(1), 90-116. https://doi.org/10.1177/1745691619868208

Gest, J., Reny, T., \& Mayer, J. (2017). Roots of the radical right: Nostalgic deprivation in the United States and Britain. Comparative Political Studies, 51(13), 1694-1719. https://doi.org/10.1177/0010414017720705 
Golec de Zavala, A., \& Cichocka, A. (2012). Collective narcissism and anti-Semitism in Poland. Group Processes \& Intergroup Relations, 15(2), 213-229. https://doi.org/10.1177/1368430211420891

Golec de Zavala, A., Cichocka, A., \& Bilewicz, M. (2013). The paradox of in-group love: Differentiating collective narcissism advances understanding of the relationship between in-group and out-group attitudes. Journal of Personality, 81(1), 16-28. https://doi.org/10.1111/j.1467-6494.2012.00779.x

Golec de Zavala, A., Cichocka, A., Eidelson, R., \& Jayawickreme, N. (2009). Collective narcissism and its social consequences. Journal of Personality and Social Psychology, 97(6), 1074-1096. https://doi.org/10.1037/a0016904

Golec de Zavala, A., Cichocka, A., \& Iskra-Golec, I. (2013). Collective narcissism moderates the effect of in-group image threat on intergroup hostility. Journal of Personality and Social Psychology, 104(6), 1019-1039. https://doi.org/10.1037/a0032215

Goodhart, D. (2014). Racism: Less is more. The Political Quarterly, 85(3), 251-258. https://doi.org/10.1111/1467-923X.12097

Gries, P., Sanders, M. A., Stroup, D. A., \& Cai, H. (2015). Hollywood in China: How American popular culture shapes Chinese views of the "beautiful imperialist" - an experimental analysis. The China Quarterly, 224, 1070-1082. https://doi.org/10.1017/S0305741015000831

Gronfeldt, B., Cichocka, A., Marchlewska, M., \& Cislak, A. (in press). From recognition to dominance: group-based needs and illiberal politics. In Sajó, A., Holmes, S., \& Uitz, R. (Eds). Routlegde Handbook of Illiberalism.

Guerra, R., Bierwiaczonek, K., Ferreira, M., Golec de Zavala, A., Abakoumkin, G., Wildschut, T., \& Sedikides, C. (2020). An intergroup approach to collective 
narcissism: Intergroup threats and hostility in four European Union countries. Group Processes \& Intergroup Relations. https://doi.org/10.1177/1368430220972178

Gudaszewski, G. (2015). Struktura narodow-etniczna, językowa i wyznaniowa ludności Polski. Narodowy Spis Powszechny Ludności i Mieszkań 2011. [The ethno-national, linguistic and religious structure of Poland. National Census of Population and Housing 2011]. Główny Urząd Statystyczny.

Hadarics, M., Szabó, Z. P., \& Kende, A. (2020). The relationship between collective narcissism and group-based moral exclusion: The mediating role of intergroup threat and social distance. Journal of Social and Political Psychology, 8(2), 788-804. https://doi.org/10.5964/jspp.v8i2.1178

Huddy, L., \& Khatib, N. (2007). American patriotism, national identity, and political involvement. American journal of political science, 51(1), 63-77. https://doi.org/10.1111/j.1540-5907.2007.00237.x

Jackson, J. S., Brown, K. T., Brown, T. N., \& Marks, B. (2001). Contemporary immigration policy orientations among dominant-group members in Western Europe. Journal of Social Issues, 57(3), 431-456. https://doi.org/10.1111/0022-4537.00222

Jardina, A. (2019). White identity politics. Cambridge University Press

Jasko, K., Webber, D., Kruglanski, A. W., Gelfand, M., Taufiqurrohman, M., Hettiarachchi, M., \& Gunaratna, R. (2020). Social context moderates the effects of quest for significance on violent extremism. Journal of Personality and Social Psychology, 118(6), 1165-1187. https://doi.org/10.1037/pspi0000198

Kaufmann, E. (2017, March 3). Racial self-interest is not racism. Ethno-demographic interests and the_immigration debate. Policy Exchange. https://policyexchange.org.uk/publication/racial-self-interest-is-not-racism/ 
Kaufmann, E. (2018). Whiteshift: Populism, immigration and the future of White majorities. Penguin Random House.

Kendi, I. X. (2020, September). Is this the beginning of the end of American racism? The Atlantic. https://www.theatlantic.com/magazine/archive/2020/09/the-end-ofdenial/614194/

Klar, Y., \& Bilewicz, M. (2017). From socially motivated lay historians to lay censors: Epistemic conformity and defensive group identification. Memory Studies, 10(3), 334346. https://doi.org/10.1177/1750698017701616

Kosterman R., \& Feshbach, S. (1989). Toward a measure of patriotic and nationalistic attitudes. Political Psychology, 10(2), 257-274. https://doi.org/10.2307/3791647

Leach, C. W., van Zomeren, M., Zebel, S., Vliek, M. L. W., Pennekamp, S. F., Doosje, B., Ouwerkerk, J. W., \& Spears, R. (2008). Group-level self-definition and selfinvestment: A hierarchical (multicomponent) model of in-group identification. Journal of Personality and Social Psychology, 95(1), 144-165. https://doi.org/10.1037/0022-3514.95.1.144

Levin, S., Federico, C. M., Sidanius, J., \& Rabinowitz, J. L. (2002). Social dominance orientation and intergroup bias: The legitimation of favoritism for high-status groups. Personality and Social Psychology Bulletin, 28(2), 144-157. https://doi.org/10.1177/0146167202282002

Lyons, M. N. (2017). Ctrl-alt-delete: The origins and ideology of the alternative right. Political Research Associates.

Marchlewska, M., Cichocka, A., Łozowski, F., Górska, P., \& Winiewski, M. (2019). In search of an imaginary enemy: Catholic collective narcissism and the endorsement of gender conspiracy beliefs. The Journal of Social Psychology, 159(6), 766-779. https://doi.org/10.1080/00224545.2019.1586637 
Meade, A. W., \& Craig, S. B. (2012). Identifying careless responses in survey data. Psychological Methods, 17(3), 437-455. https://doi.org/10.1037/a0028085

Mummendey, A., Klink, A., \& Brown, R. (2001). Nationalism and patriotism: National identification and out-group rejection. British Journal of Social Psychology, 40(2), 159-172. https://doi.org/10.1348/014466601164740

Pehrson, S., Brown, R., \& Zagefka, H. (2009). When does national identification lead to the rejection of immigrants? Cross-sectional and longitudinal evidence for the role of essentialist in-group definitions. British Journal of Social Psychology, 48(1), 61-76. https://doi.org/10.1348/014466608X288827

Pehrson, S., Vignoles, V. L., \& Brown, R. (2009). National identification and anti-immigrant prejudice: Individual and contextual effects of national definitions. Social Psychology Quarterly, 72(1), 24-38. https://doi.org/10.1177/019027250907200104

Putnam, R. D. (2000). Bowling alone: The collapse and revival of American community. Simon and Schuster.

Roccas, S., Sagiv, L., Schwartz, S., Halevy, N., \& Eidelson, R. (2008). Toward a unifying model of identification with groups: Integrating theoretical perspectives. Personality and Social Psychology Review, 12(3), 280-306. https://doi.org/10.1177/1088868308319225

Schatz, R. T., Staub, E., \& Lavine, H. (1999). On the varieties of national attachment: Blind versus constructive patriotism. Political Psychology, 20(1), 151-174. https://doi.org/10.1111/0162-895X.00140

Tajfel, H. E. (1978). Differentiation between social groups: Studies in the social psychology of intergroup relations. Academic Press. 
Turner, J. C., Brown, R. J., \& Tajfel, H. (1979). Social comparison and group interest in ingroup favouritism. European Journal of Social Psychology, 9(2), 187-204. https://doi.org/10.1002/ejsp.2420090207

van Zomeren, M., Postmes, T., \& Spears, R. (2008). Toward an integrative social identity model of collective action: A quantitative research synthesis of three sociopsychological perspectives. Psychological Bulletin, 134(4), 504-535. https://doi.org/10.1037/0033-2909.134.4.504

Winiewski, M., \& Bulska, D. (2020). Beat, ignore, force to conform: Development and initial validation of a Multidimensional Scale of Acceptance of Collective Violence. International Journal of Conflict \& Violence, 14(1). https://doi.org/10.4119/ijcv-3775 Yglesias, M. (2019, July 18). Trump's racist tirades against "the Squad," explained. Vox. https://www.vox.com/2019/7/15/20694616/donald-trump-racist-tweets-omar-aoctlaib-pressley 